\title{
JUURNAL.RU
}

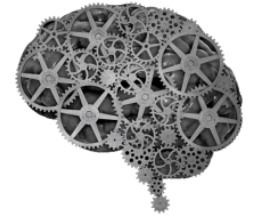

COMPANY GROUP "INTELLEKT"

\author{
Бодягина К.С., Подлепаева А.В., Солозобова Н.С., Пичхидзе С.Я. \\ СГТУ им. Ю.А. Гагарина \\ Саратов, Россия
}

doi: 10.18411/1j2016-3-05

\section{Исследование НДС зубов, восстановленных с помощью штифтов}

Применение штифтов при эндодонтическом лечении является современным и наименее затратным методом восстановления зуба. В современной стоматологии применяются металлические и неметаллические штифтовые конструкции. Самыми часто используемыми являются титановые металлические и стекловолоконные неметаллические штифты.

Целью данной работы являлось исследование влияния материала штифтов, применяемых для восстановления разрушенных зубов на напряженнодеформированное состояние зуба при жевательной нагрузке, а также на распределение силовых напряжений внутри зуба.

Исследование проводилось на конечно-элементной модели зуба, рис.1а. Размеры модели зуба соответствовали среднестатистическим размерам первого моляра нижней челюсти. Диаметр штифта - 1 мм, длина - 15 мм. Данная расчетная модель близко отражает форму и расположение элементов восстановленного с помощью стоматологического штифта естественного зуба. На рис. $1 б$ приведено разбиение модели на конечные элементы.

В данной работе при построении модели напряженно-деформированного состояния восстановленного зуба (рис. 1в) принимаются некоторые допущения: 1) корень зуба считается зафиксированным, то есть перемещения крайних точек корня зуба по всем направлениям равны нулю; 2) контакт на границе всех элементов расчетной модели считается идеальным; 3) перемещения непрерывны 
при переходе через границу контакта; 4) предполагается, что материалы работают в пределах линейной теории упругости.

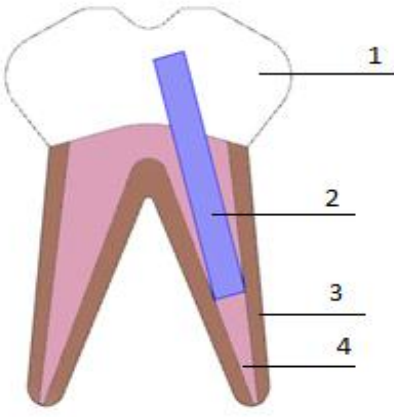

a)

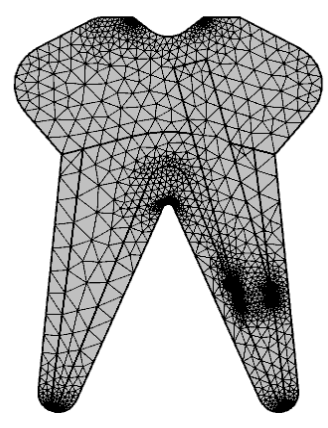

б)

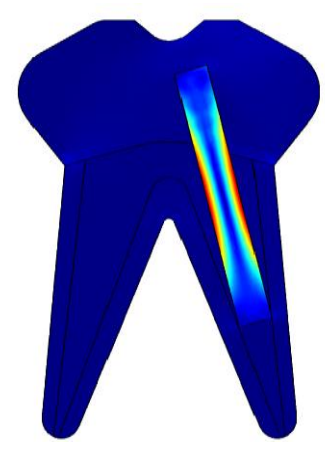

в)

Рис.1. а) расчетная модель, где: 1- керамическая коронка, 2 - штифт, 3 - дентин, 4 - пульпа, б) разбиение на конечные элементы в) НДС зуба

В ходе исследования были построены модели для штифтов двух различных материалов - титана и стекловолокна. Характеристики материалов, использованных при построении расчетной модели зуба, были взяты из [1]. Расчеты проводились при приложении нагрузок: вертикальной в 10 кН и сдвигающей в 5 кН, что соответствует естественной жевательной нагрузке. Нагрузка прикладывалась по всей верхней поверхности расчетной модели. В табл. 1 показаны максимальные напряжения в каждом из элементов расчетной модели.

Таблий 1.

Максимальные напряжения (МПа) по Мизесу в элементах модели

\begin{tabular}{|l|c|c|c|c|}
\hline \multirow{2}{*}{ Элемент } & \multicolumn{2}{|c|}{$\begin{array}{c}\text { Титановая штифтовая } \\
\text { конструкция }\end{array}$} & \multicolumn{2}{c|}{$\begin{array}{c}\text { Стекловолоконная штифтовая } \\
\text { конструкция }\end{array}$} \\
\cline { 2 - 5 } & $\begin{array}{c}\text { Вертикальная } \\
\text { нагрузка }\end{array}$ & $\begin{array}{c}\text { Сдвигающая } \\
\text { нагрузка }\end{array}$ & $\begin{array}{c}\text { Вертикальная } \\
\text { нагрузка }\end{array}$ & $\begin{array}{c}\text { Сдвигающая } \\
\text { нагрузка }\end{array}$ \\
\hline Коронка & 10,78 & 5,36 & 9,54 & 5,14 \\
\hline Штифт & 90,74 & 45,97 & 82,71 & 44,07 \\
\hline Дентин & 31,17 & 15,80 & 28,75 & 13,55 \\
\hline Пульпа & 7,81 & 3,85 & 7,21 & 4,95 \\
\hline
\end{tabular}

Как видно из табл. 1, применение стекловолоконных штифтов позволяет снизить напряжение, возникающее в зубе при жевательной нагрузке, в то время как металлические штифты концентрируют излишнюю нагрузку в области шейки зуба. Стекловолоконные штифты, благодаря их упругим характеристикам, придают большую прочность реставрациям. 
Выводы: 1) исследовано влияние материала штифтов на напряженнодеформированное состояние зуба при жевательной нагрузке; 2) показано, что стекловолоконный штифт является предпочтительным в сравнении с титановым для восстановления зубов.

\section{Литература:}

1. Лагун Ю.И. Исследование напряженно-деформированного состояния (НДС) человеческого коренного зуба // CADmaster. - 2003. -№1. - C. 34 38.

2. Бодягина К.С. Влияние формы и свойств материала реставрационной пломбы на концентрацию напряжений в зубе // Актуальные вопросы биомедицинской инженерии// - Саратов, 2013. - 613 с. - С. 538 - 546. 